\title{
SAVINGS MOBILIZATION ON POVERTY ALLEVIATION AMONG PERI-URBAN FARMING HOUSEHOLDS IN KWALI AND BWARI AREA COUNCILS F.C.T ABUJA, NIGERIA
}

\author{
Juliana Ojochide Olori, Ogechi Cordelia Nwahia*, François Sièwė \\ Department of Agricultural Economics, Ahmadu Bello University, Nigeria \\ *corresponding author: godstime_ogefine@yahoo.com
}

\begin{abstract}
Savings is increasingly being acknowledged as a powerful tool for poverty alleviation but the peri- urban households who are mostly, low cadre workers, peasant farmers and small-scale business owners lacks savings services. This study analyzed savings mobilization on poverty alleviation among peri-urban households in Kwali and Bwari Area Councils Abuja. Cross-sectional primary data was used in this study. The data was collected with the aid of a well-structured questionnaire administered to 185 peri-urban farming households. Descriptive statistics (mean, frequency and percentage), Foster Greer Thorbecke index and ordered logit regression were used to analyze the collected data. The results that emanated from the analysis reveals that $98 \%$ of respondents are within the economic active age while $82 \%$ of them had formal education and average household size of 4 person. About $93 \%$ of households saved in one form or the other. About $51 \%$ of the respondent are nonpoor while $49 \%$ are poor based on analysis of poverty status which revealed poverty incidence of $49 \%$, poverty depth of $28 \%$ and poverty severity of $56 \%$. The results further reveals that primary occupation and education reduces the likelihood of not being poor, but there is an increment in the likelihood of being very poor while farm size, savings, access to credit and income generated from secondary activities increases the probability of being non-poor, but reduces the probability of being very poor. Therefore, households should be encouraged by Governmental agencies to engage in secondary economic activities for multiple stream of income to improve on their poverty status. In addition, government should facilitate the establishment of Financial Institutions in the Peri- Urban areas to inculcate saving habit among the people.
\end{abstract}

Keywords: Savings, Mobilization, Ordered Logit Regression, Peri-Urban, Poverty.

http://dx.doi.org/10.21776/ub.agrise.2021.021.4.5

Received 4 May 2021

Accepted 13 September 2021

Available online 31 October 2021

\section{INTRODUCTION}

The economy of Nigeria as at the last quarter of 2018 advanced at $2.4 \%$ following an expansion of about $1.8 \%$ in the previous period and exceeding the market expectations gain of $2.1 \%$ (NBS, 2019). Despite this gain, 83 million Nigerians are still living in extreme poverty which is nearly $50 \%$ of its estimated population (NBS, 2019). The fight against poverty has been a key issue in development planning in Nigeria. Observers have noted that successive poverty intervention by the government have failed to achieve its objectives. Recently, saving mobilization is widely acknowledged to play an important role in poverty alleviation.

The rapid development and growth of any country is usually determined by its capital accumulation level (Uruakpa, 2018). It have been noted by the available literature that an increase in financial assets holding by the households or public, promotes mobilization of savings, which leads to higher levels of savings, high production, growth, investment, and poverty reduction (Ahmed, Awonusi, Adebanjo and Ewunuga, 2017). Savings are usually decided at the household level rather than individual (Oluwakemi, 2013). Therefore, savings mobilization is critical for households' welfare. Savings mobilization ensures that the deficit sector of the household economy are adequately funded to stimulate growth and returns (Uruakpa, 2018). Savings help households in areas such as smooth consumption, resilience to weather shocks, and to finance productive investments in human and businesses (Karlan, Ratan, and Zinman, 2013). Savings are considered as both a risk management strategy and a major determinant of investment magnitude, but its determinants and mobilization strategy are controversial issues in literature (Mkpado \& Arene, 2010). 
The financial sector plays an important role in the mobilization of savings in Nigeria. This is due to the fact that banks are veritable instrument for mobilizing resources for investment purpose. Savings is considered as the sacrifice of current consumption for the accumulation of capital which in turn, increases output to be used for future consumption (Gersouitz, 1998). Ekpung, Udude and Etim (2015), noted that mobilizing savings at the household level accords people a measure of independence and power over their earthly existence which would have been difficult if they had consumed all their incomes. Evidence have shown that the poor have demand for savings, even when formal savings products are not available, they utilizes informal method, that have high risk, high cost, and sub-optimal design (Karlan, Ratan, and Zinman, 2013). Therefore, saving mobilization could be a vital tool in their poverty reduction. Also, there is a need to integrate the informal savings institution into the formal institution in order to harness resources for economic development and increase per capital income to reduce poverty in Nigeria. This is because more capital are being held in the informal economy than the formal economy in most developing countries. Most of this capital is held in small amounts by those living near or below the poverty line (Olori, 2021).

The empirical studies conducted on savings mobilization in Nigeria focused more on rural households (Oluwakemi, 2013; Ekpung, Udude and Etim, 2015; Nuhu, Bzugu and Kwajaffa, 2015; Yusuf, Yusuf, Adesope and Adebayo, 2020), disregarding the urban and peri-urban households. Most of these studies focused on determinants of saving, but did not specifically estimate its effect on poverty. This created a bias in the data. Some other studies (Ogbonna, 2018 and Uruakpa, 2018), concentrated on the informal method of savings mobilization, disregarding the formal method. But it was not specifically on its effect on poverty alleviation. Okere and Ndugbu (2015), and Ahmed, Awonusi, Adebanjo and Ewunuga (2017), studied savings mobilization in Nigeria, but secondary data was used in this regard. Also, it was not on savings mobilization effect on poverty alleviation. This created a serious research gap which this study tends to fill. The study aimed at analyzing the effect of savings mobilization on poverty alleviation among peri-urban households in Kwali and Bwari Area Councils Abuja.

\section{METHODOLOGY.}

This study was conducted in Kwali and Bwari Area council of the Federal Capital Territory, Abuja (FCTA). FCT lies between Latitude $9^{\circ} 21$ and $8^{\circ} .25^{\prime}$ $\mathrm{N}$ and Longitude $6^{\circ} 45^{\prime}$ and $7^{\circ} 39^{\prime}$ E. It has a population of about 2.5 Million. It occupies a total land area of 8,000 sq. $\mathrm{km}$ with landscape dotted with hills, highlands and plains (FCTA Report, 2012). The FCT has boundary in the North with Kaduna state, on the East with Nassarawa state, on the South with Kogi state and on the West with Niger state. The FCT comprises of six Area Councils, namely Municipal, Gwagwalada, Kwali, Abaji, Kuje and Bwari. The climate is characterized by two distinct seasons namely the dry season and the rainly season. The dry season start from November to March and the rainy season start from April to October of each year. During the day time, the temperatures can rise to $40^{0-} \mathrm{C}$ and cools at night to $30^{\circ} \mathrm{C}$. The vegetation zone falls within guinea forest savanna. The rainfall ranges between $1100 \mathrm{~mm}$ to $1600 \mathrm{~mm}$ (FCTA online Report, 2012).

A multi-stage sampling procedure was used in the study. In the first stage, two districts were randomly selected from each of the area council of the peri- urban farming households. In the second stage, a random sampling method was employed to select two villages from each of the selected districts. Finally, 20\% of the populations of farming household were selected from each of the villages using a list compiled by the ADP staff. This is in line with Kajang, David and Jatau (2014) and adopted by Sani and Oladimeji (2017) who posited that $\geq 10 \%$ of the population is a fair representation especially where there is a large population. .A total sample size of 185 respondents was used for the study (Table 1).

Table 1: Sampling of Respondents in the Study Area

\begin{tabular}{lcccc}
\hline Area Council & Districts & Villages & (Sample Frame) & Sample Size (20\%) \\
\hline \multirow{2}{*}{ Kwali } & Kwali & Dabi & 120 & 24 \\
\cline { 2 - 4 } & & Sheda & 125 & 25 \\
\cline { 3 - 5 } & \multirow{2}{*}{ Wako } & Wako & 99 & 20 \\
\cline { 3 - 5 } & & Awawa & 120 & 24 \\
\hline \multirow{2}{*}{ Bwari } & Bwari & Ushafa & 119 & 24 \\
\cline { 2 - 5 } & & Shere & 107 & 25 \\
\cline { 2 - 5 } & Kubwa & Dutse & 125 & 22 \\
\cline { 2 - 5 } & & Dawaki & 110 & 185 \\
\hline Total & 4 & 8 & 925 & \\
\hline
\end{tabular}


Primary data were used in this study. The primary data were collected with the aid of structured questionnaire which were administered to the framing household with the help of enumerators. Information were collected on the socio-economic characteristics of the farming household which includes the household size, age of household head, educational qualification, secondary occupation, value of savings and annual income. Data were analyzed using frequency, percentage, mean, Foster Greer Thorbecke index and Ordered Logit Regression.

\section{Model specification}

Foster-Greer-Thorbecke (1984) model is specified as:

$\mathrm{P}_{\alpha}=\frac{1}{N} \sum_{t=1}^{H 1}\left(\frac{Z-Y i}{Z}\right) \alpha$

$\mathrm{P}_{\mathrm{O}}=\frac{H o}{N}$

$\mathrm{P}_{1}=\frac{1}{N} \sum_{t=1}^{H 1}\left(\frac{Z-Y i}{Z}\right)$

$\mathrm{P}_{2}=\frac{1}{N} \sum_{t=2}^{H 1}\left(\frac{Z-Y i}{Z}\right) 2$

Where,

$\mathrm{P}$ is the poverty index, $\alpha$ is the non-negative parameter, which can takes 0,1 and 2 as its value. When $\alpha$ is equal to 0 , the index gives the poverty incidence of poverty (equation 2). When $\alpha$ is equal to 1 , the index produces the depth of poverty (equation 3) and when $\alpha=2$, the index gives severity of poverty (equation 4 ). When multiplied by 100 , it gives the percentage by which a poor household's per capita annual farm income should increase to push them out of poverty.

$\mathrm{N}=$ No of the semi-urban farming households,

$\mathrm{Hi}=$ Number of poor household,

$\mathrm{Yi}=$ Per capita annual farm income,

$\mathrm{Z}=$ Poverty line, that is, $2 / 3$ of mean per capita annual farm income of the semi-urban farming households in the study areas.

\section{Poverty Line}

Per capita annual farm income was used in this study to construct the poverty line. Therefore, the poverty line is the two-thirds and one-third of the mean per capita annual farm income of the semi-urban farming households. This was also adopted by FOS (1999) and the World Bank/FOS/NPC (1998).

PCHI $=\frac{T H I}{H H S} \ldots$
MPCHI $=\frac{T H I}{T N R}$

$\mathrm{PL}=2 / 3$ or $1 / 3 * \mathrm{MPCHI}$

Where:

PCHI = Per Capita Household farm Income (Naira/Annum)

THI = Total Annual Household farm Income (Naira/Annum)

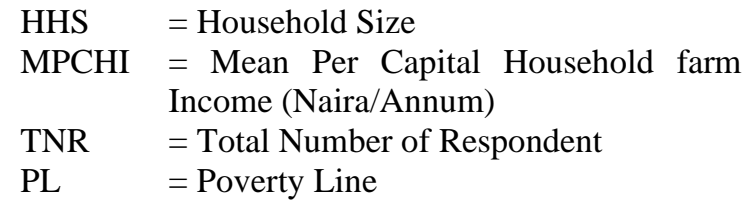

Therefore, we have three categories in this study:-

- Non-Poor: those with annual per capita income above two-third mean per capita annual income.

- Moderate Poor: those with annual per capita income between one-third and two-third mean per capita annual farm income.

- Core poor: those with annual per capita income below one-third mean per capita annual farm income.

\section{Logit regression model}

The dependent variable is the poverty status which is represented by a binary dummy (0 and 1$)$. The model is specified as:

$\mathrm{P}_{\mathrm{i}}=\mathrm{f}(\mathrm{Z})=\log \frac{p i}{1-p i} \Sigma^{\mathrm{n}}{ }_{1} \beta_{\mathrm{i}} \mathrm{X}_{\mathrm{i}}$

$P_{i}$ denotes the probability that the farming households is below or above the poverty line, $\beta_{\mathrm{i}}$ are the coefficients, $X_{i}$ are poverty determinants variables, pi is the probability of being non poor and 1 -pi is probability of being poor.

While the empirical form is stated thus:

$Y=\beta_{0}+\beta_{i} X i+e$

Where;

$\mathrm{Y}=$ Poverty status ( 1 if poor and 0 otherwise),

$X_{i}=$ parameters

i ranges from 1 to $\mathrm{N}$

Household Savings in the last 12 months in Naira,

$\beta_{0}=$ the intercept,

$\beta_{i}=$ coefficients of parameters

$\mathrm{e}=$ the error term

$Y=\beta_{0}+\beta_{1} X_{1}+\beta_{2} X_{2}+\beta_{3} X_{3}+\beta_{4} X_{4}+\beta_{5} X_{5}+\beta_{6}$

$X_{6}+\beta_{7} X_{7}+\beta_{8} X_{8}+\beta_{9} X_{9}+\beta_{10} X_{10}+e$

Where $\mathrm{Y}, \beta_{0}, e$, and $\beta_{i}$ (i ranges from 1 to 10 ) are as defined in equation 9

$X_{I}=$ Household Savings in the last 12 months in Naira,

$X_{2}=$ age,

$X_{3}=$ level of education,

$X_{4}=$ households size,

$X_{5}=$ primary occupation,

$X_{6}=$ experience,

$X_{7}=$ secondary activities,

$X_{8}=$ membership of association

$X_{9}=$ access to credit and

$X_{10}=$ farm size . 


\section{RESULTS AND DISCUSSION}

\section{Socio-economic characteristics of the respondents}

The socio-economics characteristics of the peri-urban households were analyzed using mean, percentage and frequency. The included variables are household size, level of education, age of the household head, primary occupation, sex and years of experience in primary occupation. The result of the analysis are presented in Table 2.

Table 2. Socio-economic characteristics of the respondents

\begin{tabular}{|c|c|c|}
\hline Variables & Freq & $\%$ \\
\hline \multicolumn{3}{|l|}{ Age } \\
\hline$>20$ & 8 & 19.3 \\
\hline $20-30$ & 96 & 31.9 \\
\hline $31-40$ & 58 & 27.7 \\
\hline $41-50$ & 20 & 13.9 \\
\hline$\geq 51$ & 3 & 1.8 \\
\hline Total & 185 & 100 \\
\hline Mean & 31 & \\
\hline \multicolumn{3}{|l|}{ Sex } \\
\hline Male & 109 & 59.0 \\
\hline Female & 76 & 41.0 \\
\hline Total & 185 & 100 \\
\hline \multicolumn{3}{|l|}{ Level of Education } \\
\hline No formal education & 33 & 17.8 \\
\hline Primary education & 51 & 27.6 \\
\hline Secondary education & 65 & 35.1 \\
\hline Tertiary education & 35 & 19.5 \\
\hline Total & 185 & 100 \\
\hline \multicolumn{3}{|l|}{ Household size } \\
\hline $1-3$ & 90 & 48.6 \\
\hline $4-6$ & 91 & 49.2 \\
\hline $7-9$ & 3 & 1.60 \\
\hline $10-12$ & 1 & 0.50 \\
\hline Total & 185 & 100 \\
\hline Mean & 4 & \\
\hline \multicolumn{3}{|l|}{ Primary occupation } \\
\hline Farming & 59 & 31.9 \\
\hline Trading & 67 & 36.2 \\
\hline Civil servant & 59 & 31.9 \\
\hline Total & 185 & 100 \\
\hline \multicolumn{3}{|l|}{ Years of experiences } \\
\hline $1-10$ & 126 & 68.1 \\
\hline $11-12$ & 35 & 18.9 \\
\hline $21-30$ & 17 & 9.2 \\
\hline $31-40$ & 6 & 3.2 \\
\hline$>40$ & 1 & 1.1 \\
\hline Total & 185 & 100 \\
\hline Mean & 11 & \\
\hline
\end{tabular}

Source: Field Survey, 2020
Table 2 reveals that about $32 \%$ of the semiurban farming households were within the age range of 20-30 years. The average age was 31 years. This implies that about $98.2 \%$ of the respondents are within the agriculturally active age brackets $(<20$ to 50 years). The people in this group are energetic enough to be involved in different form of livelihood activities that could generate fund for their sustenance and increase the tendency to save. Also, Table 2 reveals that about $59 \%$ of the respondents were males while $41 \%$ of them were females. This implies that male headed households were in the majority in the study area as such the propensity to save is expected to be high as farming and civil service jobs are predominantly carried out by males in the study area. This is in line with the finding of Oluwakemi (2013). Education is considered as a vital capital asset which influences savings and investment behavior of the households. However, Table 2 shows that majority $(82.2 \%)$ of the $r$ semi-urban farming households head had one form of formal education or the other. About $28 \%$ had completed primary education, and $35 \%$ had attained secondary education. Only about $20 \%$ completed their tertiary education. However, $18 \%$ had no formal education. The high literacy among the households implies a high tendency to be exposed to more reliable information sources that could greatly influence their decision making in terms of savings mobilization. Table 2 shows that about $49 \%$ of the households had between 4-7 persons while about $2 \%$ had about $8-12$ persons. The minimum household size was 2 persons while the maximum was 12 persons. The average household size was 4 indicating a tendency to saves more since the needs of members of the household may not be as big as in the household size that is large. This indicates that a substantial amount of household income will be saved due to the relatively small household expenditures. Table 2 further shows that about $32 \%$ of the semi-urban farming households were engaged in farming as their primary occupation. About $36 \%$ were involved in trading activities, while about $32 \%$ of them were civil servants. This shows that the primary occupation of most of the semi-urban households in the study area were farming and trading.

Experience influences individuals' perception and understanding of the management requirements which improve on decision making and consequently revenue. It is believed that, the higher the years of experience in occupation, the more the management ability in making relevant decision. The distribution of the semi-urban farming households according to years of experience in Table 2 depicts that $68 \%$ of them had less than 10 years occupational experience while $32 \%$ had occupational experience of between 11 years and above. It is implied from the findings that, the majority of semi-urban farming households had less 
than ten years of occupational experience. The longer an individual stays in any occupation, the more the regularity of the income which can increase savings.

\section{Savings Mobilization Strategies Adopted by Respondents}

The various forms of savings mobilization strategies adopted by different households in the study area are presented in Table 3.

Table 3. Saving Strategies used by the respondents

\begin{tabular}{lrr}
\hline \multicolumn{1}{c}{ Forms of saving strategy } & Freq & \multicolumn{1}{c}{$\%$} \\
\hline Co-operative societies & 41 & 22.16 \\
Banks & 26 & 14.05 \\
At home & 7 & 3.78 \\
Saving club (Esusu/Ajo) & 21 & 11.35 \\
Cooperative and bank & 26 & 14.05 \\
Cooperative and home & 11 & 5.95 \\
Bank, home and club & 23 & 12.43 \\
Bank, cooperative, home & 8 & 4.32 \\
and club & & \\
Bank and home & 18 & 5.32 \\
Others & 12 & 6.50 \\
Total & $\mathbf{1 8 5}$ & $\mathbf{1 0 0}$ \\
\hline
\end{tabular}

Source: Field Survey, 2020.

Table 3 shows that majority $(93.50 \%)$ of the respondents in the study area used one form of savings or the other. About $7 \%$ of them have their savings in the form of asset like land, jewelries, animals etc. Out of the majority that saved, it was discovered that about $22 \%$ preferred to save with the cooperative societies. About $14 \%$ of them saved with banks while $4 \%$ of the respondents saved at home for easy access to fund at all times. About $11 \%$ of the respondents saved with clubs (Esusu and Ajo) because of its simplicity and easy accessibility and $6.5 \%$ of them did not saved. About $47 \%$ combined different form of saving to avoid the risk of losing their hard earned money. This is in line with the finding of Adebayo (2004) and Nuhu et al. (2015), who confirmed that high percentage of households belonged to at least one savings club or the other in their respective study areas.

\section{Poverty Status of peri- urban Households}

The households' poverty status were analyzed using three indicators; poverty incidence (Po), poverty depth (P1) and severity of poverty (P2) computed using the FGT Index. Results of poverty analysis are presented in Table 4 . To determine the poverty status of the households, a common base line (poverty line) was established. The poverty line was determined using two third mean per capita household farm incomes (MPCHI) in the study area. A relative poverty line of $¥ 208,704.50$ was established. Sequel to this, households having an average annual farm income above $\$ 208,704.50$ was considered non-poor, those with income between $\$ 104,352.25$ and $\$ 208,704.50$ are considered moderately poor while those having annual average farm income less than $104,352.25$ were considered very poor as shown in Table 4 .

Table 4. Poverty Statuses and Indices of peri- urban Household

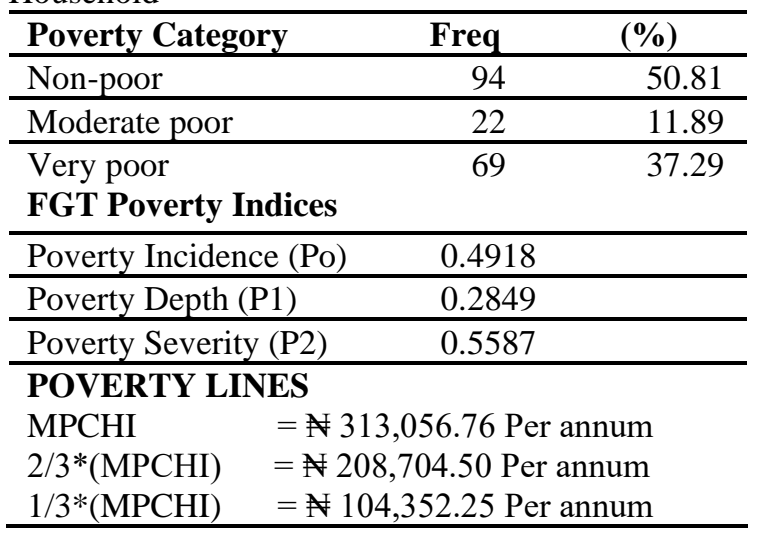

Table 4 reveals that about $51 \%$ of the respondents were non-poor, while about $12 \%$ were moderately poor and about $37 \%$ were very poor. That is to say that about $49 \%$ of the households were poor because their incomes level fell short of the poverty line. The result of the poverty incidence among the sampled households was 0.4819 , which imply that about $48 \%$ of the peri-urban household in the study area were poor. The poverty gap index of the poor households was 0.2849 which means that about $28 \%$ of the total incomes are required to bring individuals within the poor households up to the poverty line of $208,704.50$. The implication is that respondents among the poor household need about $28 \%$ which gives additional $\$ 58,437.26$ to their mean per capita annual farm income to come up to the poverty line. The poverty severity index of the households was 0.5587 . This implies that poverty is more severe among poor respondents with about $56 \%$ of the selected households that constitute the poorest among the respondents.

\section{Effect of Household Savings on Poverty Status}

The ordered logit regression was used to estimate the effect of households' savings on poverty and the results are presented in Table 5. 
Table 5. Ordered logit regression of the effect of households' savings on poverty status

\begin{tabular}{|c|c|c|c|c|}
\hline \multirow[b]{2}{*}{ Variables } & \multirow[b]{2}{*}{ Coefficients } & \multicolumn{3}{|c|}{ Marginal effects } \\
\hline & & $\begin{array}{c}\text { Pr (Poverty } \\
\text { status=1) }\end{array}$ & $\begin{array}{c}\text { Pr (Poverty } \\
\text { status=2) }\end{array}$ & $\begin{array}{c}\text { Pr (Poverty } \\
\text { status=3) }\end{array}$ \\
\hline Savings & $-2.035(0.735) * * *$ & $0.135(0.054)^{* * *}$ & $0.006(0.003)^{*}$ & $-0.141(0.053)^{* * *}$ \\
\hline Age & $-0.059(0.033)^{*}$ & $0.004(0.002)^{*}$ & $0.000(0.000)$ & $-0.004(0.003)^{*}$ \\
\hline Level of education & $0.541(0.264) * *$ & $-0.036(0.019)^{*}$ & $-0.002(0.001)$ & $0.037(0.020)^{*}$ \\
\hline Household size & $-0.459(0.346)$ & $0.030(0.022)$ & $0.001(0.001)$ & $-0.032(0.023)$ \\
\hline Primary occupation & $0.692(0.304)^{* *}$ & $-0.046(0.017)^{* * * *}$ & $-0.002(0.002)$ & $0.048(0.019)^{* * *}$ \\
\hline Experience & $-0.004(0.028)$ & $0.000(0.002)$ & $0.000(0.000)$ & $-0.000(0.002)$ \\
\hline $\begin{array}{l}\text { Secondary } \\
\text { activities }\end{array}$ & $-0.974(0.538)^{*}$ & $0.065(0.037)^{*}$ & $0.003(0.002)$ & $-0.067(0.039)^{*}$ \\
\hline Association & $0.980(1.025)$ & $-0.065(0.067)$ & $-0.003(0.003)$ & $0.068(0.069)$ \\
\hline Credit & $-1.328(0.747)^{*}$ & $0.088(0.043)^{* *}$ & $0.004(0.004)$ & $-0.092(0.045)^{* *}$ \\
\hline Farm size & $-1.562(0.913)^{*}$ & $0.103(0.051)^{* *}$ & $0.005(0.005)$ & $-0.108(0.055)^{*}$ \\
\hline Log likelihood & -51.084 & & & \\
\hline Wald Chi2(10) & $53.82 * * *$ & & & \\
\hline Prob>Chi2 & 0.0000 & & & \\
\hline No of observation & 185 & & & \\
\hline
\end{tabular}

Note: ***,**,* Significant at 1\%,5\%,10\% levels respectively.

Poverty status: 1 = Non-poor; 2 = Moderate poor; 3 = Very poor

NOTE: Figures in parentheses are standard error.

The estimate of ordered logit regression in Table 5 shows that the model fits the data well as the model likelihood ratio test (Wald Chi ${ }^{2}(10)=53.82$; Prob $\left.>\mathrm{Chi}^{2}=0.0000\right)$ shows a good fit for the model. The results shows that the effects of some of the socioeconomic variables on the poverty status differ substantially across the model. From the result, as household size increases the saving intensity, there is $14 \%$ increase in probability of not being poor, $0.6 \%$ increase in the probability of being moderately poor, and $14 \%$ reduction in the probability of being very poor. This shows that with more savings, there is tendency to have more financial power to make effective management decisions regarding investment, thereby reducing household poverty status. There is $0.4 \%$ reduction in the probability of being poor as the household head grows older. This is possible because older household heads are most times in possession of additional assets and have more business opportunities that enlist them to be out of poverty. The outcome result of level of education shows that as the household head increases in the level of formal schooling, there is reduced likelihood of not being poor, while there is increased likelihood of being very poor without formal education. The implication of this is that level of education increases the level of poverty. The justified reason for this is that educated household may likely see some income generating activities as non-decent enough for their educational status, thereby loosing so many incomes generating opportunities coupled with high rate of unemployment in the country. However, this is against the a priori expectation and contradicts the assertion of Duniya and Rekwot (2015) who states that education is the most important factor in poverty reduction. However, this finding of increase poverty with increase in educational qualification can be attributed to the high rate of unemployed educated people of all cadre in Nigeria in recent time.

The primary occupation of household was found to reduce the likelihood of being non-poor, whereas it increases the probability of being very poor. Plausible reason could be that household gets less paid jobs not good enough to take care of themselves talk less having to save. Household with secondary sources of income aside their primary activities are less prone to be poor. An increase in income generated from secondary activities, increases the probability of being non-poor by $7 \%$, while it also reduces the probability of being very poor by $7 \%$. Moreover, there is $9 \%$ increase in the probability of being non-poor, and also $9 \%$ reduction in the probability of being very poor by households who had access to credit. This means that household who had access to credit can invest in business opportunities to enhance their income level, thereby increasing their standard of living. Also the farm size owned was found to have a significant effect on poverty status. As the size of farm land owned increases, there is $10 \%$ increment in the probability of being non-poor, and reduces the probability of being very poor by $10 \%$. This is because an increase in farm size enables the farming households to cultivate more to increase production which also increases their income level. Farmland owned is also considered as a great asset which can 
be leased out, or used for further production process. This is in line with Nwahia et al. (2020).

\section{CONCLUSION AND RECOMMENDATION}

Savings is increasingly being acknowledged as a powerful tool for poverty reduction. This study focused on the effect of saving mobilization on poverty alleviation among peri-urban households in two districts of the FCT. The study established that overwhelming majority (98\%) of respondents are within the economic active age while $82 \%$ of them had formal education and average household size of 4 person. About $93 \%$ of the households saved in one form or the other. The study further established that primary occupation and education reduces the likelihood of not being poor, but there is increased likelihood of being very poor while farm size, savings, access to credit and income generated from secondary activities increases the probability of being non-poor, but reduces the probability of being very poor. Therefore, households should be encouraged by Governmental agencies to engage in secondary economic activities for multiple stream of income to improve on their poverty status. In addition, government should facilitate the establishment of Finance Institutions in the PeriUrban areas to inculcate saving habit among the people.

\section{REFERENCE}

Adebayo, C.O. (2004). Analysis of Rural Savings Mobilization for Poverty Alleviation in Ijumu Local Government A rea of Kogi State.Unpublished M.Sc. Thesis Department of Agricultural Economics, Ahmadu Bello University, Zaria.

Ahmed, A.V., Awonusi, F., Adebanjo, J. F., and Ewunuga, Y.A. (2017). Financial Sector Reforms and Savings Mobilization in Nigeria (1980 - 2013), CARD International Journal of Management Studies, Business \& Entrepreneurship Research, Vol, 2 (2) pp 2545-5885.

Duniya, K. P., and Rekwot, G. Z. (2015). Determinants of Poverty among Groundnut Farming Households in Jigawa State, Nigeria. Asian Journal of Agricultural Extension, Economics \& Sociology, 4(3): 224-230.

Ekpung, E. G., Udude, C. C., and Etim, B. S. (2015). Rural Saving Mobilizations and Economic Development in Akamkpa Local Government Area of Cross River State, Nigeria, Journal of Challenes, vol 2(1)pp 14-29.

FCTA (2012), Federal Capital Territory Administration Report. Retrieved on August $5^{\text {th }}, 2013$ from www.fct.gov.ng.
Foster, Greer, J.J. and Thorbecke, E. (1984) A Class of Decomposable Poverty Measure, Econometrical. 52:761-766.

FOS. (1999) Poverty Profile for Nigeria 1980 - 1996. Federal office of statistics, Abuja, Nigeria. Pp. 12-15.

Gersovitz, M. (1998). "Saving and Development". In H. Chenery and I.N. Scrinivason, (eds) Handbook of development economics. North -Holland: Elsevier Science Publishers.

Kajang, G. Y., David, J. G., and Jatau, A. A. (2014). Research and Statistics Made Simple in Education. Champman Printing Press, Kaduna, Nigeria. PP 87.

Karlan, D., Ratan, A.L., and Zinman, J. (2013). Savings By and For the Poor: A Research Review and Agenda, Economic Growth Center Discussion Paper No. 1027.

Mkpado, M. and Arene, C.J. (2010). Does group design affect savings mobilization of rural Agricultural micro credit groups? Evidence from Nigeria. Economic Affairs 55(3/4): 231-242.

Nuhu, H. S., Bzugu, P.M., and Kwajaffa, A.P. (2015). Determinants of Savings among Rural Women in Borno State, Nigeria, Asian Journal of Agricultural Extension, Economics \& Sociology 5(4): 202-214.

National Bureau of Statistics (NBS). (2019). 2019 Report on Poverty and Inequality in Nigeria, Abuja.

Nwahia, O. C., Sièwè, F., and Onyeabor, E. N. (2020). Determinants of Poverty Status among Rice Farming Households of USAID-Markets II Project in Ebonyi State, Nigeria, Journal of Agricultural Economics, Extension and Social Sciences, $J A E^{2} S^{2}$, Vol. 3(2) pp. $90-96$.

Ogbonna, S.I. (2018). Informal Savings Strategies among Farm Headed Households in Ohafia Local Government Area of Abia State, Nigeria: A Gender Situation Analyses, Nigerian Agricultural Journal, Vol. 49 (2) Pp. 284-293.

Okere, P.A., and Ndugbu, M. (2015). Macroeconomic Variables and Savings Mobilization in Nigeria, International Journal for Innovation Education and Research Vol. 3(1) pp 105 -116.

Olori, J.O. (2021). Savings Mobilization on Poverty Alleviation among Peri-Urban Households in Kwali And Bwari Area Councils F.C.T Abuja, Nigeria, An unpublished M.Sc Thesis, Ahmadu Bello University, Zaria, Nigeria.

Oluwakemi , A. O. (2013). Determinants of Savings Rate in Rural Nigeria: A Micro Study of Kwara State, Journal for the Advancement 
of Developing Economies, Vol. 2 (1) pp 114.

Sani, A. A., and Oladimeji, Y. U. (2017). Determinants of Technical Efficiency among Sorghum Farmers under ATA in Gombe State, Nigeria. Nigerian Journal of Agriculture, Food and Environment, 13(3): $122-127$.

Uruakpa, P. C. (2018). Do Informal Financial Institutions in Nigeria Matter for Savings, Investment and Growth? International Journal of Banking and Finance Research (IIARD), Vol.4 (3), pp $30-46$.
World Bank/FOS/NPC. (1998). Poverty and Welfare in Nigeria" World Bank/Federal Office of Statistics/National Planning Commission, Abuja, Nigeria. PP 1-22.

Yusuf, W.A., Yusuf, S. A., Adesope, A. A. A., and Adebayo, A. A. (2020). Assessment of Factors Influencing the Saving Culture among Rural Households in Ibarapa East Local Government of Oyo State, Nigeria, Journal of Research in Forestry, Wildlife \& Environment Vol. 12(1) 156 - 166. 